\title{
Market Orientation Adoption Strategies for Small Restaurants: A Study in the Eastern Sri Lanka
}

\author{
Mohamed Ismail Mujahid Hilal \\ Senior Lecturer \\ Faculty of Management \& Commerce \\ South Eastern University of Sri Lanka \\ Kaldeen Mohamed Mubarak \\ Senior Lecturer \\ Faculty of Management \& Commerce \\ South Eastern University of Sri Lanka
}

\begin{abstract}
The main aim of the study is to investigate the adoption and application of market orientation by small restaurants in the Eastern Sri Lanka. In order to achieve this aim, 21 small restaurants were drawn from the Eastern part of Sri Lanka. Findings suggest that small restaurants are unable to adopt market orientation strategies. Components of market orientation such as customer orientation, competitor orientation and inter functional coordination are with insignificant correlation and hence, the components of market orientation are not adopted by small restaurants. Monitoring the changes in the customer needs is essential for the success of these firms in the industry. Though these firms are small, competitors' analysis has to be done and the results should be used as input for the development of competitive strategy. Inter functional coordination is also playing major role in this business to become market oriented
\end{abstract}

Key words: Market orientation, small restaurants, customers, business performance

\section{Introduction}

An organization, to gain competitive advantage in the industry, needs to understand and anticipate customers today (Hanzaee, et al., 2012). Many marketing literatures suggest that putting marketing concept in force in an organization, is a foundation for successful performance of business. Marketing concept is that achieving organization's goals depends on the needs and wants of target market and deliver the desired satisfaction effectively and efficiently than competitors (Kotler and Keller, 2006). By understanding the customer needs and behavior, organizations realize superior performance better than competitors (Day, 1994).

The marketing concept that has existed for many years was one of the first strategic frameworks that provided firms with a sustainable competitive advantage (Kumar et al., 2011). Market orientation means the implementation of the marketing concept. Hence, a market-oriented organization is one whose actions are consistent with the marketing concept (Kohli and Jaworski, 1990). Marketing orientation is used as an 
indicator for implementing marketing concept in the organization (Agarwal et al., 2003).

Previous researches have been curried on the relationship between marketing orientation and business performance. However, most of these researches attempted to study the linkages between these two major variables such as market orientation and firm's negative or positive performance depending on their level of existing organizations' innovativeness (Verhees and Meulenberg, 2004). Marketing orientation is considered as a strategy to improve the business performance (Narver and Slater, 1990; Jaworski and Kohli, 1993; Chang and Chen, 1998).

Small restaurants in the Eastern Sri Lanka have potential of earning substantial profit in their business if they are successful in attracting and retaining customers. Most of the organizations fail in short term without generating enough income. The linkages between marketing orientation and their business performance need to be studied in order to ensure their survival of these small restaurants in the industry. Further, market orientation creates strongest convictions that it largely contributes to the firm's performance more than what innovation, learning and entrepreneurial orientations (Grinstein, 2008).

The hotels and restaurants sub sector contributes 0.5 percent to the Gross Domestic Product and this sector has recorded a 22.6 percent growth rate during the first half of 2012. Further Sri Lankan government has set a target to attract 2.5 million tourists by 2016. This has formed an opportunity for number of business such as construction industry, domestic agriculture, food, hotel and beverages industry (Dailynews, 2012). GDP of Sri Lanka is increasing annually and it has good economic growth for the last few years after the prolonged civil war.
After the war, private and government companies are expanding their business activities to the North and to the East of Sri Lanka. Tourist arrival into the country is also increasing tremendously not only to the city areas in Sri Lanka but other areas like Eastern province of Sri Lanka. The increase of tourists in the Eastern Sri Lanka leads to open up new restaurants which cater to needs of local and foreign tourists who visit tourist destinations in the East part of Sri Lanka.

While tourism picks up and lucrative opportunities are opening up in the Eastern region of Sri Lanka, it is likely that these small restaurants can be sustainable without shutting down their business provided that these small restaurants can follow the concept of market orientation. It is because of the fact that market orientation can be a source of competitive advantage when it is observed as value for customers which cannot be imitated (Singh, 2009). Also market orientation obviously creates superior value for customers (Aziz and Yasin, 2004).

Hence, this paper is done on the following line. Firstly, this paper discusses past studies on market orientation which explain market orientation and its importance to the business organizations. Secondly, research problem is discussed and thirdly, aim of the research and specific objectives of the study are given. Fourthly, research design is elaborated which includes theoretical framework and operationalisation, data collection and data analysis. Finally, results and discussion on findings and conclusion are given at the end.

\section{Literature review}

Paul (2006) states that market orientation is implementing the marketing concept, it is therefore action oriented. It has positive 
influence on business performance. Marketing orientation is defined as the processes and activities coupled with creating and satisfying customers by continually assessing their needs and wants and doing so in a way that there is a confirmable and measurable impact on business performance. Market orientated culture assists marketers to monitor how competitors and customers move in the industry (Lin et al., 2008).

The concept of marketing orientation is derived from the marketing concept because the market oriented firm is one which successfully applies the marketing concept. According to McGee and Spiro (1998), success of organization depends on the determination and satisfaction of the needs, wants and aspiration of targets markets. This must be carried out effectively and efficiently than competitors with the intention of profitability. Therefore, if an organization achieves profitability and its objectives, the entire organization should focus on satisfying consumer needs, wants and aspirations. Thus, marketing orientation derives from the application of marketing concept.

Narver and Slatter (1990) present three components of market orientation such as customer orientation, competitor orientation and inter functional coordination. Customer orientation means that the company must sufficiently understand the target buyers and so that continuous superior value can be created for them. According to competitor orientation, organization clearly understands the short term strengths and weaknesses and long term capabilities of both current and potential competitors. Inter functional coordination implies that integration of all function in the organization to create superior customer value.
Kholi and Jaworski (1990) define marketing orientation as the organization wide generation of market intelligence pertaining to current and future customers' needs dissemination of the intelligence across departments and organization wide responsiveness to it.

Marketing orientation is vital for any organization. If the organization does not have market orientation, it is very difficult to implement and control marketing activities effectively since the organization will not have marketing plans. The marketing orientation will cause improved organization effectiveness because it improves the marketing effectiveness of an organization (Richard and Colin, 2001).

There are different explanations for market orientation by various researchers. For example Navdeep and Raghbir (2004) elaborate the components of market orientation includes top management's emphasis, intelligence dissemination, reward system, responsiveness, interdepartmental conflict, top management's risk aversion and interdepartmental connectedness.

George and Spiros (1990) pointed out that the following two pillars of marketing orientation are inseparable are interrelated. However, for marketing orientation to be developed, companies as well its behavior must be adjusted accordingly.

“The company's attitude to perceive marketing orientation as the company's philosophy, which is grounded on the persistence to analysis and understand the market prior to any action" and the company's behavior to collect intelligence about the market, disseminate it company-wide and to design the company's response on the basis of this market-intelligence." (George and Spiros, 1999) 
According to Lloyd (2000), three structural (connectedness, centralization

and formalization), two strategic (service and cost focused strategy) and three systematic (communication system, integration devices and marketing function controlled co-ordination and it was suggested that there are direct and indirect skills. Thus, he developed a broader classification of factors associated with market orientation. In accordance with these finding, we can conclude that marketing orientation is determined by not only the factors such as company specific factors and market specific factor but there are factors such as organizational structure, strategy and system characteristics are also associated with marketing orientation.

\section{Developing better measure for market orientation}

Brendan et al (1998) found that market orientation is multi dimensional construct consisting of five sub dimensions. This can be used to measure the market orientation of a company. These five sub dimensions are customer orientation, competitor orientation, inter-functional co-ordination, and responsiveness and profit emphasis. Further, Brendan et al. (1998) support the instruments developed by Jaworski and Kholi (1993) scales to measure the market orientation. The implication of his research is that successful implementation of marketing concept produce concrete customers and organizational benefit and if the attention is paid by mangers towards these five dimension help improve company performance and assist in identifying the area of weakness and taking remedial action for diagnosed weaknesses.

In relation to small and medium enterprises, Charles and Julian (2005) revealed that the market orientation consists of four dimensions and it is consistent with Kohli and Jaworski's (1990) construct. These four dimensions are; concern for staff (providing a good working environmental and remuneration, and responding to changing customer need, Awareness of the market environment (undertaking formal market research and responding to the changing customer needs), business profitability/objectives(ensuring that both long and short term objectives are met and that the business is profitable) and customer services (ensuring that employees are motivated and committed to provide a high level of customer service.)

\section{Market orientation and corporate success}

Wolfgang (1996) found in his research that the market orientation is also one of the important aspects of corporate management along with the production/cost orientation and employee orientation. It is further noted that market orientation is an important critical factor for the corporate success. If the market orientation removed from the firm then it would be serious mistakes. Hence, the market orientation is the one of the major factors for corporate success.

Despite the fact that there is a relationship between performance of an organization and marketing orientation, marketing orientation is not sufficient for superior performance and it is also not an essential condition for superior performance. Further, he argued that although it is probably true that market orientation is positively related to business performance more effort should be directed at exploring what lies beneath the relationships (Chiquan, 2002).

Market orientation is essential for any organization for being successful in their business. Further, there are findings from the literatures with regard to the relationship between market orientation and superior 
business performance. This relationship may be questionable among small restaurants in the Eastern Sri Lanka. There was no research curried out among small restaurants in the East part of Sri Lanka while the contribution of this sector to the GDP is growing immensely. Hence, this study focuses on adoption of market orientation by small restaurants and to find actions that restaurants should attempt in order to ensure the survival of their business and make substantial profit.

\section{Statement of the problem}

Small restaurants in the Eastern Sri Lanka are unable to attract customers and are unable to generate substantial profit. These newly established restaurants are competing each other for their survival and comparatively their business performance is very low due to inability of generating substantial profit. The ultimate survival of these restaurants depends on the successful customer attraction, retention of these customers and increased business performance. No research so far focused on these small restaurants in Sri Lanka. Hence, it is essential to study the extent to which these small restaurants are adapting the market orientation to increase the marketing and financial performance in order to survive in the dynamic competitive environment. This study generates insight into whether market orientation is practiced by the small restaurants in the Eastern Sri Lanka and helps understand the extent to which the market orientation is adopted by these small restaurants.

\section{Aim and objectives of the study}

The main aim of the study is to investigate the adoption and application of market orientation by small restaurants in the Eastern Sri Lanka. The specific objectives of the research are;
- To identify the variables which most suitable for restaurants adoption of market orientation.

- To understand impacts of market orientation on the performance of restaurants in the region.

- To identify the factor that underpins market orientation of small restaurants.

- To evaluate market orientation adoption by the small restaurants.

\section{Research design}

\section{Theoretical framework and Operationalization}

Many researchers find that there is a strong relationship between marketing orientation and business performance (For instant, Kohli and Jaworski, 1990; Narver and Slater, 1990; Chang and Chen, 1998). Further, Jaworski and Kohli (1990) suggest that managers of organizations should strive for the improvements in the market orientation in order to increase the business performance. Matsuno et al. (2002) found a significant positive relationship between a market orientation and measures of both financial and marketing performance. Firms that adopt market orientation early will gain more in sales and profits than firms that are late to develop market orientation (Kumar et al., 2011).

Kohli and Jawrski (1990) and Narver and Slater (1990) received importance among the researches curried on market orientation. Kohli and Jaworski (1990) identified components of market orientation such as wide generation of marketing intelligence with regard to current and future customer needs, dissemination of intelligence across departments and organization wide responsiveness to this intelligence. In this study, the components of market orientation 
identified by Narver and Slater (1990) has been used.

Jaworski and Kohli (1993) further explained the importance of market orientation on business performance. Market orientation is important determinant for organization which strives for attaining higher business performance.

In view of the relationship between market orientation and profitability, Narver and Slater (1990) stressed that marketing orientation is with continuum due to which business having high degree of market orientation is associated with the highest profitability. Further, it was revealed that the study by Narver and Slater (1990) was vital first step in validating the positive relationship between market orientation and business performance.

Subsequently, other investigations (Dobnl and Luffman, 2000; Qu, 2007; Kirca, et al., 2005) also suggest that organizations with market orientation associated with superior performance such as profitability, sales growth and new product success. It is because of the fact that organizations will have greater understanding of customers' wants and latent needs, capabilities and strategies of competitors, channel requirements and developments and the broader market environment than its rivals (Hult and Ketchen, 2001). Further, there is strong evidence that market orientation significantly impacts both financial and marketing performance (Green Jr et al, 2005).

Accordingly, the conceptual framework for the study is shown in the Figure 1.

As per the conceptualized model, three variables such as customer orientation, competitor orientation and inter functional coordination makes up market orientation in an organization for a small restaurant. Narver and Slater (1990) emphasized customer orientation, competitor orientation and inter functional co-ordination and these components of market orientation are positively related to business performance. According to Narver and Slater (1990), firm should identify its customers and understand behavior of target buyers so that firm can continuously create superior value for customers. Competitor orientation in the sense, firm understands its competitors' short and long term capabilities of present and potential competitors. Inter-functional coordination means that coordinated resources in the organization must be utilized for creating superior value for customers.

Figure 1. Conceptual framework

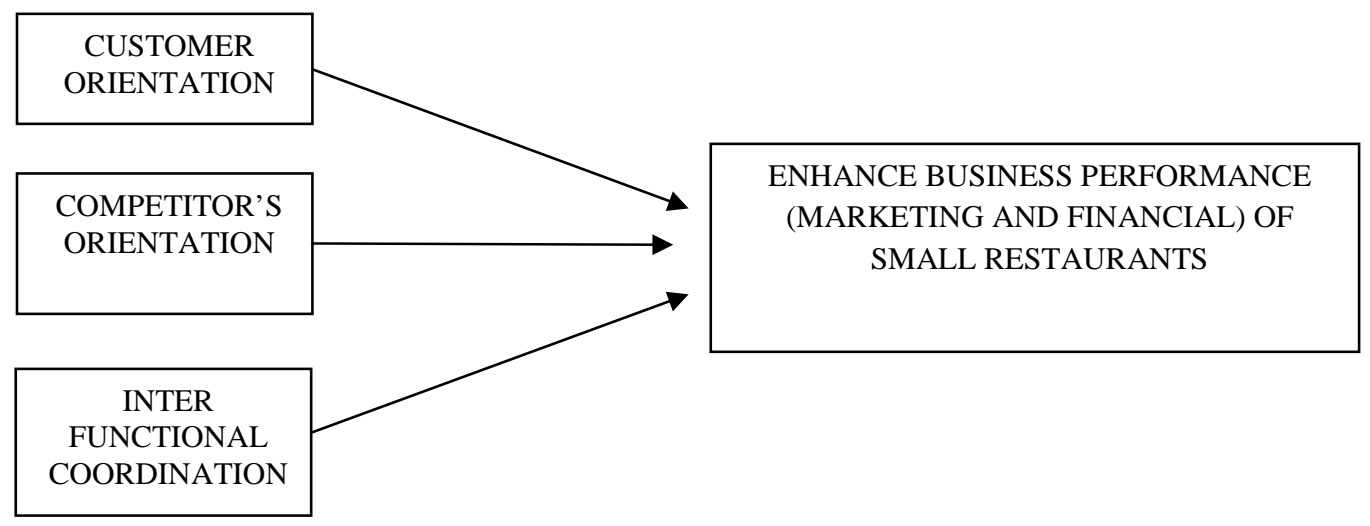

Source: Adopted from Narver and Slater (1990) 
As far as business performance is concerned, business performance should include marketing and financial performance (Day and Wensley, 1998). Further most of the researchers measure the business performance subjectively. Researchers measure links between market orientation and business performance using secondary data on business performance and found that there is positive association between market orientation and firm's performance (Eg. Morgan, et al., 2009). In the present study, researcher measures the business performance subjectively comparing with competitors' performance. Factors such as sales growth, profitability and market share, new product development and return on investment can be used to measure business performance (Nwokah, 2008; Matanda and Ndubisi, 2009).

Despite the fact that all literatures are suggesting strong positive relationship between market orientation and business performance, there is a question whether these small restaurants are adopting marketing orientation and has increased business performance.

Therefore, researcher hypothesizes that;

Adoption of market orientation by small restaurants leads to the improvement of business performance

\section{Data collection}

Target population for the study was managers or owners of selected small restaurants in the Eastern Sri Lanka. Researchers followed convenient sampling technique for selecting these small restaurants. A small restaurant for this study is defined as a restaurant with at least five employees, which deliver special meals for both local and foreign customers three times a day with or without any accommodating facilities.
Data was collected from 21 restaurants in Ampara, Batticaloa and Trincomalee in the Eastern Sri Lanka. A questionnaire was prepared by adapting sets of statements for each component in the market orientation validated measurements scales from previous research. The scale measurements developed by Matanda and Ndubisi (2009) were used for this research. The questionnaire consists of 15 statements and respondents were asked to scale on the 7 point likert scale.

Researcher directly had a meeting with some of these small restaurants in the Eastern province of Sri Lanka and filled the questionnaires. Research assistants were also deployed for this survey in the research areas. Some of the respondents were left with questionnaires for filling it. These respondents were reminded by telephone calls and later dully filled questionnaires were collected from them.

\section{Data analysis}

Since the questionnaire was taken from previous research, the validity and reliability of these questions have already been established (see Matanda and Ndubisi, 2009; Oczkowski and Farrel; 1998). According to literatures, this instrument has received eminence among various scholars. SPSS 14 was used to analyze the data. Hence, the researchers have carried out factor analysis in order to infer correlations between major variables. In the factor analysis, the communalities and rotated component matrix were derived from the analysis.

Communalities were above 0.5 for customer orientation and business performance. Under competitor orientation and under inter functional coordination, the communalities for one item in each component were below 0.5. Hence, particular item was dropped and again factors were loaded for inter functional coordination 
and for competitor orientation. In the rotation techniques, varimax was selected and the rotated component matrix was derived. This was used for identifying which factor was influencing more on the components. Communalities and rotated component matrix are given in the Apendix 1. Finally, correlation analysis was performed in order to see the contribution of each component of market orientation to the business performance of these small restaurants.

\section{Results and Discussion}

The model conceptualized in this study for testing is not best fit. That is, small restaurants do not implement marketing concept. They, therefore, are not market oriented. Hence, the hypothesis is not accepted. In the components of market orientation, customer orientation, competitor orientation and inter functional coordination are playing major role in determining the survival of these small restaurants in the Eastern province. If these restaurants had been market oriented, these components of market orientations should have contributed to higher business performance. Components of market orientation have not contributed to higher business performance. Correlation coefficients are given in Table 1.

Communalities and rotated components of factor analysis results in the SPSS are given in the Appendix 1. All items under customer orientation are with values greater than 0.5. Data collected for customer orientation has been incorporated for this research. For the component competitor orientation, item number 5 (We always try to match the performance of other restaurants in the business) is with value less than 0.5 and therefore the item was dropped and factors were reloaded. The same procedure was done for the item number 4 (Everyone who works here can competently handle customer queries) under inter functional coordination.
Correlation between customer orientation and business performance 0.092 and it is not significant $(p=0.691)$ which is greater than probability value of $0.05(p>0.05)$. This implies that customer orientation does not contribute to the business performance. This is also proved with the scatter plot which is shown in the Figure 1.

Table 1 Correlation coefficient and significant

\begin{tabular}{|l|l|l|l|}
\hline $\begin{array}{l}\text { Orientation } \\
\text { Components }\end{array}$ & $\begin{array}{l}\text { Business } \\
\text { performance }\end{array}$ & $\begin{array}{l}\text { Sig.(2- } \\
\text { tailed) }\end{array}$ & $\mathrm{N}$ \\
\hline $\begin{array}{l}\text { Customer } \\
\text { orientation }\end{array}$ & .092 & .691 & 21 \\
\hline $\begin{array}{l}\text { Competitor } \\
\text { orientation }\end{array}$ & .312 & .169 & 21 \\
\hline $\begin{array}{l}\text { Inter } \\
\text { functional } \\
\text { coordination }\end{array}$ & .375 & .094 & 21 \\
\hline
\end{tabular}

According to the literature, customer orientation means that small restaurants will have to understand the target buyers and superior value should be created for them continuously. This has not been done in these small restaurants. Small restaurants should take efforts to monitor the changes in the needs of customers and small restaurants should adopt them for the improvements of the business performance. Employees and top management can regularly talk to the customers who come to the restaurants or feedbacks can be taken from the customers by a small market surveys. Through such a survey, these firms can also evaluate the customer preferences towards these small restaurants. Despite the fact that many factors (5 items) make up customer orientation, monitoring the needs of customers, evaluation of customer preferences and new product ideas from customers are vital for these restaurants among five items to increase the business performance since the rotated component values are very high for these items (See Appendix 1). 
Competitor orientation is a major part of market orientation of a firm. A firm should focus on the activities of current and potential competitors to a firm. As organization these small restaurants have to monitor their competitors' actions in the environment.

Figure 1 Scatter plot (customer orientation and business performance)

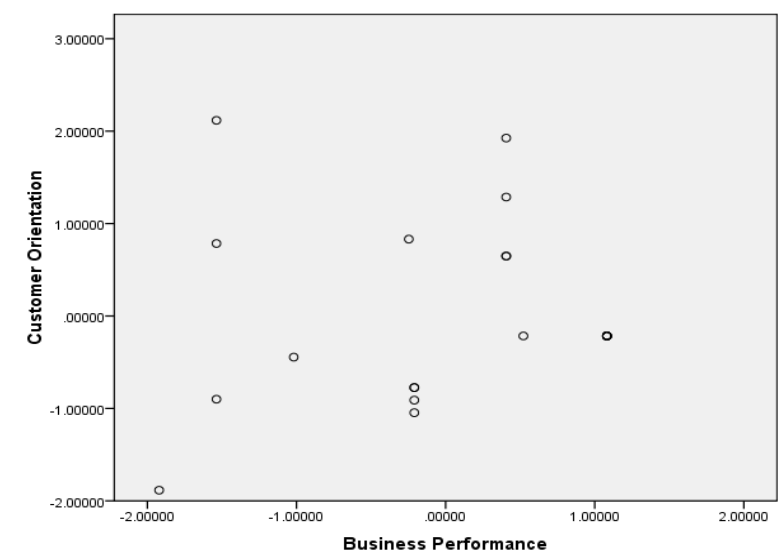

The contribution of competitor orientation to business performance of small restaurants in the Eastern Sri Lanka is also not significant, which shows that restaurants are not adopting competitor orientation. This is shown in Table 1 as Correlation coefficient is 0.312 ( $p=0.169$ which is greater than the probability value of 0.05) which is not significant. Small restaurants in the Eastern Sri Lanka do not understand the short term strengths and weakness clearly. They are unable to compare their long term capabilities of current and potential competitors. Another reason for the insignificant relationship is top management of these small restaurants do not regularly discuss competitors' actions with their employees. While discussing about their competitors' actions, top management have to take necessary competitive responses in order to overcome competitors' attack. Further, these firms may take measures to observe regularly the pricing moves which competitors do for their food. Among these items that make competitor orientation, discussion about competitors between top management and responses to competitors' moves are important because these two items are with rotated component values are 0.821 and 0.853 respectively.

Inter functional coordination is important for any organization to be market oriented. This means a firm should take measures to ensure communication between functional areas of business that helps organization to create superior customer value and thereby both internal and external customers are served effectively. Correlation coefficient between variables inter functional coordination and business performance of small restaurants is insignificant $(r=0.375, p=0.094)$.

This is shown in Figure 3 which implies that inter functional coordination does not contribute to the business performance of small restaurants in the Eastern region. Although these firms are small, top management at these firms should attempt to discuss about competitive strategy against competitors with restaurants' employees. Further, these restaurants should freely communicate market performance and business performance among its employees which help generate additional ideas from them and it can be incorporated in the competitive strategy development.

Figure 2 Scatter plot (competitor orientation and business performance)

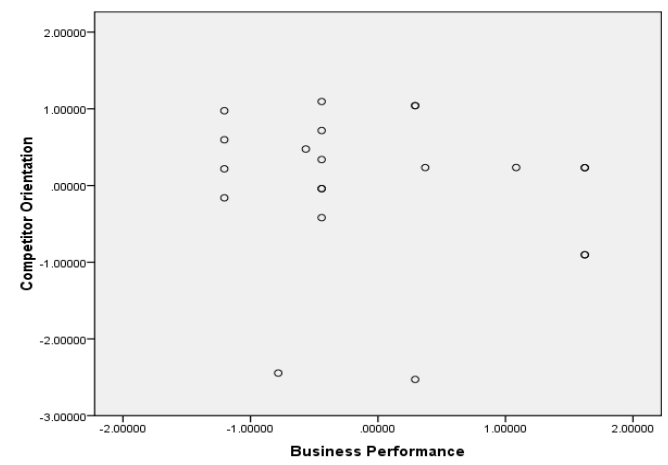


Workers at small restaurants should focus on understanding customer value. All workers must strive for creating value for customers. Lack of marketing knowledge among employees and top management may be a cause for this insignificant relationship between these variables. Inter functional coordination can lead to business performance of small restaurants if it can adopt the above stated suggestions in their business. Especially, among five items, customer value and communicating business performance are with 0.864 and 0.947 of rotated component value respectively. Hence, small restaurants have to give attention to these two items to improve its inter functional coordination.

Figure 3 Scatter plot (Inter functional coordination and business performance)

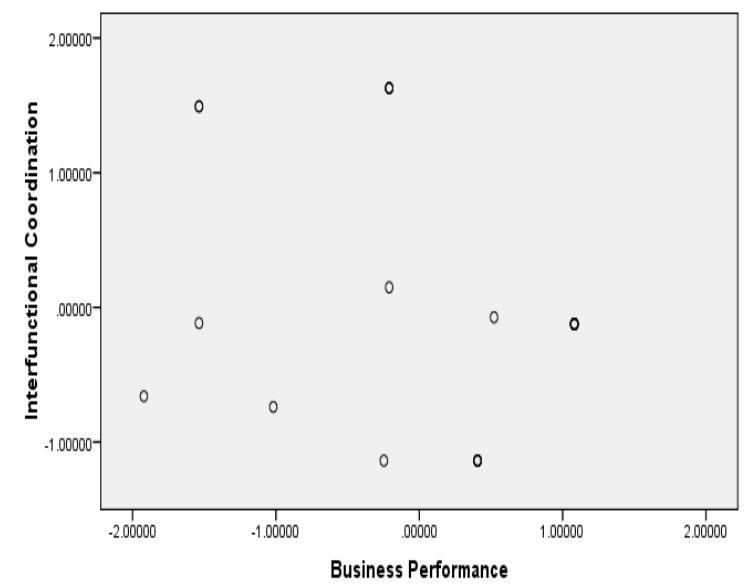

\section{Conclusion}

The results indicate that three components of market orientation such as customer orientation, competitor orientation and inter functional coordination do not contribute to the business performance of small restaurants in the Eastern region of Sri Lanka. Small restaurants in the Eastern region have to be customer focused. Monitoring the changes in the customer needs is essential for the success of these firms in the industry. Though these firms are small, competitors' analysis has to be done and the results should be used as input for the development of competitive strategy. Inter functional coordination is also playing major role in this business to become market oriented. For that, top management of these small restaurants should take steps to discuss market performance and business performance with their workers. In case these firms adopt market orientation, as Richard and Colin (2001) suggested, marketing orientation will lead to marketing effectiveness at small restaurants and consequently, there would be improved organizational effectiveness.

Though it is concluded that if these firms are successful in business performance, marketing orientation should be followed, further studies should be carried out on marketing capabilities of these small restaurants in the Eastern region of Sri Lanka in order to find marketing inabilities and educate top management of these firms on how to be market oriented in the particular industry.

In summary, small restaurants are unable to adopt market orientation and as a result, these firms are likely to be unsuccessful in the industry and this may lead to business failure. Hence, these firms should attempt to follow market orientation to increase their business performance.

\section{References}

Agarwal, S., Erramilli, M. and Dev, C. (2003), "Market orientation and performance in service firms: role of innovation", Journal of Services Marketing, Vol. 17 No. 1, pp. 68-82.

Aziz, N.A. and Yasin, N.M. (2004), "The influence of market orientation on marketing competency and the effect of internet-marketing integration', Asia Pacific Journal of Marketing and Logistics, Vol. 16 No. 2, pp. 3-19. 
Brendan G., Shellagh M., and Phil M. (1998), Developing a better measure of market orientation, European Journal of marketing, vol. 32, Iss. 9/10, pp. 884-903.

Charles B. and Julian M.C., (2005), Have Small Business Adopted the market orientation concept?, The case of small business in Michigan, Journal of Business \& Industrial Marketing, Vol. 20, No. 6, pp. 317 - 330.

Chang, T. and Chen, S. (1998), "Market orientation, service quality and business profitability: a conceptual model and empirical evidence", Journal of Services Marketing, Vol. 12 No. 4, pp. 246.

Chiquan G., (2002), market orientation and business performance: framework for service organization, European Journal of marketing, Vol. 36, Iss. 9/10, pp. 1154-1163.

Dailynews (2012), Tourist arrivals up by 18.7 percent, December 16, p.

Day, G. and Wensley, R. (1988), “Assessing advantage: a framework for diagnosing competitive superiority", Journal of Marketing, Vol. 52, No. 2, April, pp. 1-20.

Day, G.S. (1994), "The capabilities of marketdriven organizations", Journal of Marketing, Vol. 58, No. 4, pp. 37-52.

Dobnl, C.B. and Luffman, G. (2000), "Market orientation and market strategy profiling: an empirical test of enviornment-behaviour-action coalignment and its performance implications", Management Decision, Vol. 38 No. 8, pp. 50319.

George J. and Spiros P.G., (1999), Marketing Orientation and its determinants: an empirical analysis, European Journal of Marketing, Vol. 33, Iss. 11/12, pp. 1003-1037.
Green Jr K.W., Inman R.A., Brown G., Willis T.H (2005), Market orientation: Relation to structure and performance, Journal of Business \& Industrial Marketing, Vol. 20, No. 6, pp. 276 -284 .

Grinstein A. (2008), The Relationships between Market Orientations and Alternative Strategic Orientations: A Meta Analysis, European Journal of Marketing, Vol. 42, No. 1/2, pp. 115134.

Hanzaee K.H, Nayebzadeh S., Jalaly M., (2012), The Effect of Market Orienation, Innovation and Customer Loyalty on Firm's Performance (Case Study: Islamic Clothing Manufacturing Company), Journal of Basic and Applied Scientific Research, Vol. 2, No. 4, pp. 32253234.

Hult GT, Ketchen DJ Jr. (2001), Does market orientation matter? A test of the relationship between positional advantage and performance, Strategic Management Journal, Vol. 22, No. 9, pp. 899-906.

Jaworski B.J. and Kohli K.A (1993), Market Orientation: Antecedents and Consequences, Journal of Marketing, Vol. 57, No.3, pp. 53-70.

Kohli K.A. and Jaworski B.J., (1990), Market Orientation: The Construct, Research Proposition and Managerial Implication, pp. 1 18.

Kotler P and Keller K.L. (2006), Marketing Management, Pearson Education, India.

Kumar V., Jones E.V, Rajkumar, V., Leone R.P. (2011), Is Market Orientation a Source of Sustainable Competitive Advantage or Simply the Cost of Competing?, Journal of Marketing, Vol. 75, Iss. 1, pp. 16-30.

Lin C.H, Peng C.H, Kao D.T (2008), The Innovativeness Effect Market Orientation and 
Learning Orientation on Business Performance, International Journal of Manpower, Vol. 29, Iss 8, pp. $252-772$.

Lloyd C.H (2000), The Organizational Barriers to Developing Market orientation, European Journal of Marketing, Vol. 34, Iss. 5/6, pp. 598624.

Matanda M.J. and Ndubisi N.O. (2009), Market orientation, supplier perceived value and business performance of SMEs in a Sub-Sahran African nation, Journal of Enterprise Information Management, Vol. 22, No. 4, pp. 384-407.

Matsuno, K., Mentzer, J.T. and Ozsomer, A. (2002), "The effects of entrepreneurial proclivity and market orientation on business performance", Journal of Marketing, Vol. 66 No. 3, pp. 18-32.

McGee and Spiro (1988), The Marketing Concep in Perspective, Business Horizons, May - June, pp. 40-50.

Morgan N.A., Vorhies D.W and Mason C.H. (2009), Market Orientation, Marketing Capabilities ad Firm Performance, Strategic Management Journal, Vol. 30, pp. 909-920.

Narver John C. and Stanley F. Slater (1990), The Effect of Market Orientation on Business Profitability, Journal of Marketing, 54 (October), pp. 20-35.

Navdeep, A. and Raghbir S., (2004), Market Orientation in Indian Organizations: An Empirical Study, Marketing Intelligence \& Planning, Vol. 22, Iss. 7, pp. 700-715.

Nwokah N.G (2008),"Strategic market orientation and business performance: The study of food and beverages organizations in Nigeria",
European Journal of Marketing, Vol. 42, Iss: 3 pp. $279-286$

Oczkowski, E. and Farrell, M.A. (1998), "Discriminating between measurement scales using non-nested tests and two-stage least squares estimators: the case of market orientation", International Journal of Research in Marketing, Vol. 15 No. 4, pp. 349-66.

Paul D.E.,(2006), Market Orientation and Performance: A Meta - Analysis and Cross National Comparison, Journal of Management Studies, Vol. 43, No. 5, pp. 1089-1107.

Qu, R. (2007), "The role of market orientation in the business success of MNCs' UK subsidiaries", Management Decision, Vol. 45 No. 7, pp. 1181-92.

Richard M.S.W, Colin G., Strategic Marketing Management, Second Edition, (New Delhi: Viva Books, 2001).

Singh R. (2009), Mind the gap: Unlocking the relationship between market-orientation and service performance, Library Review, Vol. 58 Iss: 1 pp. $28-43$

Verhees, F.J.H.M, and Meulenberg M.T.G (2004), Market Orientation, Innovation, Product Innovation and Performance in Small Firms, Journal of Small Business Management, Vol. 42, No.2, pp. 134-154.

Wolfgang F. (1996), Market orientation and corporate success: Findings From Germany, European Journal of Marketing, Vol. 30, Iss. 8, pp. 59-74. 


\section{Appendix 1}

\begin{tabular}{|c|c|c|}
\hline Items & Communalities & $\begin{array}{c}\text { Rotated } \\
\text { component } \\
\text { matrix }\end{array}$ \\
\hline \multicolumn{3}{|l|}{ Customer orientation } \\
\hline $\begin{array}{l}\text { We frequently and systematically monitor the needs of our } \\
\text { customers }\end{array}$ & .813 & .878 \\
\hline We get ideas about new products and services from our customers & .521 & .679 \\
\hline We regularly talk to our customers & .921 & .260 \\
\hline We regularly evaluate customer preferences & .716 & .808 \\
\hline We regularly discuss our customers' needs & .880 & .066 \\
\hline \multicolumn{3}{|l|}{ Competitors orientation } \\
\hline We regularly discuss about what our competitors are doing & .725 & .821 \\
\hline $\begin{array}{l}\text { If our competitors launch a campaign to promote their products } \\
\text { we respond immediately }\end{array}$ & .865 & .853 \\
\hline We respond rapidly to pricing moves made by our competitors & .844 & .425 \\
\hline Top managers regularly meet to discuss competitor capabilities & .723 & -.213 \\
\hline $\begin{array}{l}\text { We always try to match the performance of other restaurants in } \\
\text { the business }\end{array}$ & - & - \\
\hline \multicolumn{3}{|l|}{ Inter functional coordination } \\
\hline $\begin{array}{l}\text { We take time to discuss our competitive strategy with other } \\
\text { managers in our restaurants }\end{array}$ & .897 & -.306 \\
\hline $\begin{array}{l}\text { Everybody here understands how everyone can create value for } \\
\text { customers }\end{array}$ & .749 & .864 \\
\hline $\begin{array}{l}\text { Information about market performance is freely communicated to } \\
\text { everybody }\end{array}$ & .803 & -.561 \\
\hline $\begin{array}{l}\text { Everyone who works here can competently handle customer } \\
\text { queries }\end{array}$ & - & - \\
\hline $\begin{array}{l}\text { Information about the business performance is freely } \\
\text { communicated to all who work here }\end{array}$ & .939 & .947 \\
\hline \multicolumn{3}{|l|}{ Business performance } \\
\hline Sales volume & .882 & -.915 \\
\hline New product development & .934 & .862 \\
\hline Increased market share & .907 & .943 \\
\hline Return on investment & .903 & -.159 \\
\hline Profit margin & .635 & .244 \\
\hline
\end{tabular}

